This is a self-archived - parallel published version of this article in the publication archive of the University of Vaasa. It might differ from the original.

\title{
Typologies of internationally mobile employees
}

Author(s): Andersen, Maike; Dickmann, Michael; Suutari, Vesa

Title: Typologies of internationally mobile employees

Year: $\quad 2018$

Version: Accepted manuscript

Copyright (C)2018 the authors, Palgrave Macmillan, Cham.

\section{Please cite the original version:}

Andersen, M., Dickmann, M., \& Suutari, V., (2018). Typologies of internationally mobile employees. In: Dickmann, M., Suutari, V., \& Wurtz, O., (eds), The Management of global careers : exploring the rise of international work (pp. 33-61). Palgrave Macmillan, Cham. https://doi.org/10.1007/978-3-319-765297_2 


\section{Chapter 2: Typologies of Internationally Mobile Employees}

\section{Maike Andresen, Michael Dickmann, \& Vesa SuutarI}

In Dickmann, M., Suutari, V. \& O. Wurtz (eds), The Management of Global Careers: Exploring the Rise of International Work. Palgrave.

\section{Introduction}

International business needs require many employees to execute international work. Companies that need experienced leaders in new markets often mobilize managers for a long term foreign assignment. When technical workers need to realize a short-term project in a foreign subsidiary, they may be assigned abroad for a short term. In order to negotiate a contract with a foreign customer, employees may take an international business trip. Others may decide to commute between countries so as not to uproot family, either to meet a shortterm business requirement abroad or because the employee lives in a different country than where the workplace is located. Other companies again require their employees to execute mobile jobs that involve on-the-job-mobility, e.g. in the transport and logistic sector (e.g., truck drivers on long-distance routes, mariners) or the service sector (e.g., journalists, pilots, stewards) (Otto \& Dalbert, 2010). As the realm of international business grows and changes, so do the types of international work-related mobility that support it. Thus, internationally operating companies nowadays need to administer many different forms of international work.

When counting the number of internationally mobile employees (IMEs) and analyzing the consequences of international mobility in order to improve the management of different kinds of IMEs, who counts as an expatriate (and its variants) is of crucial importance. Yet there is no consensus on a single definition of, for example, a 'self-initiated expatriate' or a 'migrant' (e.g. Anderson \& Blinder, 2015). Tharenou (2015), in a comparative review of the literatures on assigned expatriates (AEs), self-initiated expatriates (SIEs) and skilled immigrants, recently 
warned not to combine these conceptually distinct groups of globally mobile individuals, as doing so contaminates the results, posing a threat to the validity of our findings. In pursuit of exactness, preciseness and completeness, we find many authors who seek to define (new) types of IMEs based on an increasing number of criteria. We want to question the added value of doing so and formulate a plea for a sound theory of expatriation types.

\section{Definitions and typologies}

When summarizing the literature on international mobility we find a long list of types of internationally mobile employees. Briscoe, Schuler and Claus (2009) were one of the first to draw our attention to this terminological development by providing a valuable overview of terms used in research and practice. Appendix 1 gives an overview about different typologies of internationally mobile persons as found in literature.

From our extended list of different types of internationally mobile persons (see Appendix 1), three things become apparent: (1.) Numerous criteria are used to define types that refer to mobility, employment, and conditions (see Appendix 2). This reflects the fact that typologies, by definition, are based on a limited number of theoretically meaningful dimensions (Doty \& Glick, 1994). However, depending on the theory or conceptual model used, the criteria usually differ between authors resulting in different types. (2.) The criteria are, however, not used consistently across all typologies so that demarcations between types are not always distinct on the one hand and some overlaps exist on the other hand. (3.) To describe one type of IME a single criterion is sometimes used differently by authors, leading to contradictions, as we will show in the following chapter. (4.) The major disadvantage of typologies is that empirical evidence running counter to theoretical specifications may not be strong enough to discover inherent weaknesses of the typology (Bailey, 1994). Hence, in the following we aim to critically analyze existing typologies of internationally mobile employees including the criteria used. 
This attempt to differentiate an increasing number of different types of IMEs is comparable to a double-edged sword. On the one hand, precise sampling allows scientists to derive precise implications for a specific subgroup of IMEs. Thus, practitioners get very clear answers to how to manage specific IMEs. On the other hand, a highly differentiated typology requires employers to develop a range of differentiated policies instead of standardized rules, involving organizational costs. Moreover, a differentiation of types also requires scientists to agree on criteria and definitions and to use these consistently. Strikingly, only very few authors in the field of expatriation disguise the specific items or selection criteria they used to specify their sample. This implies that studies that used the same term to designate their type of IME, might in fact have different definitions in mind and have included different types in their sample, which again reduces the comparability of results between studies. Furthermore, the transferability of research results to other subgroups is open in view of a lack of replication studies with different subgroups.

In view of the increasing number of typologies and types of IMEs developed by researchers, this long list of criteria used to define types, and the overlap in the definitions of these types as well as a lack of clarity, we plea for preciseness and a sound theory of expatriation. We quest for using few criteria leading to general ("rough") types (see Andresen, Bergdolt, Margenfeld, \& Dickmann, 2014), that allow for clear sampling strategies in empirical research and the development of targeted policies in practice.

\section{Quest for developing a theory of international employee mobility}

Overall, the numerous existing types of IMEs in literature and practice are a highly differentiated, practical system of statements about different forms of international mobility. Do we still need a scientific alternative in this case? Would it be an option to make existing typologies in research and practice a little more explicit by collecting all types of IMEs and 
fixing them in writing, comparable to the list in Appendix 1? Would that lead to a scientifically sound theory of expatriation and a useful typology?

We can only answer this question by, first, establishing criteria for a science and then examining whether the ordinary typologies of IMEs (as presented in Appendix 1) meet these criteria of a science. Most sciences are at least entitled to satisfy the following quality criteria: General criteria include explicitness, consistency, completeness, parsimony, productivity, and applicability (Asendorpf \& Neyer, 2012). Additional criteria are empirical anchoring and empirical testability (see Table 1):

\begin{tabular}{|l|l|}
\hline Criteria & \multicolumn{1}{l|}{ Explanation } \\
\hline General Criteria & \\
\hline Explicitness & The terms and statements of the typology are to be explicitly stated. \\
\hline Consistency & $\begin{array}{l}\text { The statements that can be derived from the typology shall not be } \\
\text { contradictory. }\end{array}$ \\
\hline Completeness & $\begin{array}{l}\text { The statements of the typology shall explain all known phenomena of the } \\
\text { subject matter of the typology. }\end{array}$ \\
\hline Parsimony & The typology is intended to deal with as few basic concepts as possible. \\
\hline Productivity & $\begin{array}{l}\text { The typology is intended to create new research questions and thereby } \\
\text { promote research. }\end{array}$ \\
\hline Applicability & The typology should be applicable practically. \\
\hline Additional criteria for empirical sciences \\
\hline $\begin{array}{l}\text { Empirical } \\
\text { anchoring }\end{array}$ & $\begin{array}{l}\text { The concepts of the typology should refer directly or indirectly to } \\
\text { observational data. }\end{array}$ \\
\hline $\begin{array}{l}\text { Empirical } \\
\text { verifiability }\end{array}$ & $\begin{array}{l}\text { The statements of the typology shall be verifiable based on observational } \\
\text { data. }\end{array}$ \\
\hline
\end{tabular}

Table 1: Criteria for theories in the (empirical) sciences (Asendorpf \& Neyer, 2012)

In the following, we evaluate typologies of IMEs according to these criteria that characterize science. We refer to a selection of types (i.e. migrant, immigrant, SIE, AE) to illustrate our argument that probably represent the majority of the existing types of IMEs.

Explicitness: Scientific terms, in our case types of IMEs, need to be explicitly defined so that they are understood in the same way by different scientists and, ideally, practitioners. The increasing number of types presented in literature (e.g. Arp, Hutchings, \& Smith, 2013; Baruch, Dickmann, Altman, \& Bournois, 2013; McPhail, Fisher, Harvey, \& Moeller, 2012; Tharenou, 2015) risk to remain vague (see McNulty \& Brewster, 2016 for a critique) and are 
used by different people in a similar, but not identical way. For example, the term migrant, as typical in economics, is sometimes assumed to refer to (a.) permanent moves of (b.) lower skilled labor (c.) from developing countries (see e.g. Al Ariss, 2010). This definition contradicts the broader definition of migrants in sociology and economics that covers all qualification levels (see e.g. 'highly skilled migrants', Chaloff \& Lemaitre, 2009) and includes both temporary and permanent mobility (e.g. Massey \& Bartley 2006; Wiles, 2008) from both developing and developed countries (Stilwell, Diallo, Zurn, Vujicic, Adams, \& Dal Poz, 2004). Moreover, when researchers in the field of expatriate management are asked for a definition of an ordinary expatriate type, such as a "self-initiated expatriate", they have to think hard in order to reconstruct the meaning quite appropriately. What does "self-initiated" mean? Strikingly, only very few definitions of SIEs explicitly address criteria of initiative (for an exception, see Andresen et al., 2014; see also Selmer, Andresen, \& Cerdin, 2017 for a critique) and most authors do not present the items they used to identify SIEs in their sample.

Consistency: In research as well as in public statistics about international labor mobility, contradictory assertions are often found, as Anderson and Blinder (2015) critically point out. For example, "Migrants might be defined by foreign birth, by foreign citizenship, or by their movement into a new country to stay temporarily (sometimes for as little as a year) or to settle for the long-term.” (Anderson \& Blinder, 2015: 3). Some definitions of migrants even include children who are born in or are nationals of the country they live in, but whose parents are foreign-born or foreign-nationals (Anderson \& Blinder, 2015). It becomes obvious that none of these definitions are equivalent and distinct. Taking only the example of the term 'migrant', contradictions in terms of length of stay (permanent versus temporary stay) and birth/citizenship become obvious. This raises the question in how far research results and statistics are comparable and transferable. 
Moreover, the terms 'immigrant' and 'migrant' are sometimes used interchangeably among researchers (e.g. Tharenou, 2015), while others distinguish immigrants (people who are or intend to be settled in their new country) from migrants (who are temporarily resident) (see Anderson \& Blinder, 2015). McNulty and Brewster (2016), by contrast, suggest a contradictory definition of migrants as used in economics and politics by claiming that migrants move permanently to another country. This shows clear inconsistencies in the use of technical terms between, and sometimes even within disciplines.

In addition, demarcations of migrants and immigrants from self-initiated expatriates are not unambiguous. So, Tharenou (2015) defines SIEs as persons who expatriate for a temporary, but undefined time, whereas skilled (im)migrants are defined to expatriate "for the long-term usually to settle permanently" (Tharenou, 2015, p. 162; see also Cerdin \& Selmer, 2014). This distinction is relativized by the explanation that "SIEs can also be 'immigrants' if a visa and residence permit are required" (Tharenou, 2015, p. 150) and, thus, risks to be perceived as being inconsistent by some readers.

Inconsistent typologizations of IMEs explain every state of affairs, so also its opposite, and thus nothing: it is only an apparent explanation. Inconsistent typologies seem to be true because they provide an explanation for everything. While we agree with McNulty and Brewster (2016) that a good theory of expatriation requires consistency, we claim that their limitation to the criterion of consistency is insufficient. Rather, sound theories need to fulfill additional criteria, as will be shown in the following.

Completeness: Theories should explain all that is already known. This is one of the strengths of the extensive typologies of international mobile employees that have been suggested in the past (e.g. Baruch et al., 2013; Briscoe et al., 2009; see also Appendix 1), because of the huge amount of types and criteria that can be used for a categorization of expatriates. With the numerous typologies that have been suggested by researchers almost all 
observable peculiarities can be explained (and named). This is, however, sometimes bought by a lack of absence of contradiction. Suggested types become vague when we talk about transitions between types. The following example is meant to show ambiguities in existing types that appear when taking a life-course perspective: A couple intends to work and live in China. She manages to be assigned by her employer to China for 4 years. He accompanies his wife as trailing spouse and after they got settled he starts looking for a job one year after relocation. He gets a job offer after one year of applications. Thus, during this two years long period of unemployment the husband holds migrant status, but is not an expatriate (see sources indicated in Andresen et al., 2014). Does the husband become a self-initiated expatriate after these 24 months of unemployment and is he loosing migrant status then? In how far did he show (proactive) initiative or just respond to the situation that his wife was assigned abroad? After the official ending of her assignment, the couple decides to continue to stay abroad for a temporary, but undefined time. She applies for a new job by changing employers. Does she become a SIE although she already lived in China since 4 yours and thus did not self-initiate her expatriation for this specific step in her career? What does the self-initiation relate to - to the decision to go abroad or to any decision to change employers during a stay abroad? After several prolongations of their stay, they finally look back to 15 years in China. Did they both become immigrants in the meantime in view of their long-term stay and, if yes, at which point of time? And, a somewhat heretical question, do we need types and names for all of these tiny differences and for which purpose?

In this vein, based on a systematic literature review Andresen et al. (2014) define international migrants as individuals who move from one geographical point to another geographical point, crossing national borders, and change their dominant place of residence which is the center of their life. An expatriate is a migrant who executes legal work abroad. While in the case of SIEs, the first key binding activity to move internationally is solely made 
by the individual who initiates the expatriation and the legal decision of employment is made by a new work contract partner, in the case of AEs, the first key binding activity to expatriate is taken by the organization and the legal decision of employment is made by the current work contract partner, usually in the home country.

Parsimony: Existing typologies of IMEs are extremely rich in basic coverage, because every type of international mobility is a basic concept (it is not derived from other basic assumptions). For example, Briscoe et al. (2009) distinguish between 20 different kinds of IMEs in their typology. There are, therefore, at least as many basic concepts as there are words to characterize international employment mobility properties. Such an abundance of basic assumptions cannot necessarily be justified by the complexity of the subject matter, as a glance at chemistry shows where the huge variety of substances can be attributed extremely economically to combinations of few elements. Even though such a drastic reduction regarding criteria and forms of international mobility may not be possible, the great number of almost synonymous features of different types appears far too uneconomical (see Andresen et al., 2014). Long lists of types of IMEs based on numerous criteria massively violate the principle of parsimony.

Productivity: The existing extensive lists of types of IMEs constitute a rich reservoir of properties which offer almost unlimited possibilities for investigations into the function of certain properties and their couplings. However, there is a tension with the ability to combine insights from research as the existence of so many diverse definitions and specific international mobility types evokes the risk of spreading into narrow and non-interrelated research questions. One way to overcome this tension would be to distinguish between broad criteria that can be used to develop different foci. Highly productive approaches allow the accumulation and integration of research insights due to having an agreed set of fundamental criteria while at the 
same time opening up the possibility to employ diverse perspectives and to pursue a wide array of research questions when honing in within the different fundamental types.

Applicability: As we have seen, the strength of extensive typologies of IMEs lies in its simple, fast and robust applicability to ordinary problems in the field of international relocation. This is why extensive IME typologies prove themselves good despite the weaknesses mentioned above. However, a comprehensive typology based on numerous criteria may take more time to be applied, look complex, and be harmed by overlaps between types. From a practitioner's point of view, categorizing employees in numerous different types in order to offer type-specific HR practices might not be applicable and economic.

Today's management research is also understood as an empirical science, which, like natural sciences, physics, chemistry, and biology, is based on observational data, and its statements can be confirmed or disproved by observation. In addition to the general criteria already discussed, empirical sciences must satisfy two supplementary criteria (see Table 1):

Empirical Anchoring: Body size is a property that can be observed directly. Attitudes, motivations and dispositions, by contrast, are not directly observable and measurable, but can only be derived from statements or behavior. They are constructs "behind" the observable behavior and should explain it. The intention to stay abroad is a construct that is intended to explain the observation that someone is showing particular or very little relocation mobility behavior. Constructs need to be linkable to observational data (the empirical indicators of the construct). The measurement procedure is also called the operationalization of the construct.

Are ordinary typologies of IMEs empirically anchored? At first sight, this seems to be the case, because typologies were partly determined based on directly observable properties (e.g. educational level), but mostly derived from behaviors (e.g. motives) of IMEs. However, one of the main problems of these ordinary typologies is that only very few requirements are imposed on the conditions under which researchers may conclude from observations of 
behaviors on types of international mobility. Interestingly, more than 100 articles about SIEs have been published, but no agreed-on operationalization of "self-initiation" has been presented yet, let alone that similar criteria have been used to identify SIEs, making the study results more or less incomparable. In consequence, the requirements regarding SIEs' behavior to be observed are imprecise. Is it sufficient that people have changed employers when going abroad? What does that tell about their initiative?

Thus, ordinary typologies of IMEs risk to be insufficiently anchored empirically. In particular, the imprecise definition of behavioral regularity regarding the initiative suggests a circular closure in the definition of SIEs: From a one-time behavior it is concluded to a mobility type, that is then used to explain regular behavior. Example: "Why is Anna a self-initiated expatriate? Because she showed personal initiative when going abroad." However, the fact that she self-initiated her expatriation does not imply that Anna in general shows personal initiative. Rather, a general personal initiative would require that Anna regularly shows initiative, i.e. throughout her relocation process as well as in her work. And this would need to be proven by observations based on numerous incidents. In other words, there is an observable risk that researchers and practitioners overgeneralize from a one-time behavior (e.g. a self-initiated expatriation) to a generally high trait (e.g. personal initiative) of a certain type of IMEs (Vance, 2005).

Empirical testability: Empirical sciences are expected to be empirically testable. More specifically, their statements are expected to be empirically confirmable or disprovable. To this end, they must be formulated clearly so that such a test is possible. The lack of explicitness and the insufficient empirical anchoring of many characteristics of ordinary types of IMEs complicate such a test because any statement can be immunized against a refutation by appropriate modification of the explanation. 
The following wxamples illustrates the mechanism of suitable modifications in explanations of ordinary types of IMEs: "Anna has been categorized as migrant in official statistics, because she moved abroad in order to stay temporarily in the host country. Looking back, Anna has been staying in the host country for 20 years. Does this mean that the typologization as migrant is wrong? To immunize against this reproval, one explanation could be that Anna changed her mind while being abroad and now intends to stay permanently (and, thus, became an immigrant only later-on). If this is not the case, another explanation could be used by arguing that she stuck to her initial plan to stay temporarily, but prolongated her stay again and again. Finally, if this is disproved one could again argue that Anna privately wanted to stay permanently, but was not sure whether she would pass immigration requirements upon relocation and, thus, indicated a conservative plan." In this example, one explanation is replaced by another explanation and as it does not prove to be plausible, again another explanation can be sought to justify the initial classification as migrant.

Since explanations and predictions of single IME types are arbitrarily modifiable and, thus, avoid any refutation, this also applies to IME typologies as a whole. If you cannot refute single types as the conditions are quite broad then it is clear that the whole typology cannot be refuted. This is the greatest weakness of many typologies from an empirical point of view.

\section{Further reflection on these typologies}

This section outlines first some of the practical drawbacks of not having agreed, consistent global types of IMEs. Second, it will investigate the tension between a broad and agreed typology and specific research interests further and will suggest a way forward.

Given the more than three dozen different forms of IMEs identified (see Appendix 1), the space in this chapter is insufficient to discuss the effects of definitional shortcomings on all of these. Instead, we will concentrate on a few global career types. Taking the example of AEs - those company-sent global careerists who have been covered most in the literature - we can 
start to explore the impact of the lack of a widely accepted, high quality definition on the recommendations for individuals and organizations. Using the four phases of the expatriation cycle as depicted in Dickmann and Baruch (2011), an array of issues, questions and shortcomings are raised.

Global Mobility Strategies, Structures and Policies and Individuals. Organizations determine the underlying goals and configurations of their international mobility (IM) often geared to traditional AEs. Several ways to design IM strategies and to structure their global mobility departments are possible (RES Forum, 2015). Where companies have a highly integrated international HR approach (a global or transnational configuration according to Bartlett and Ghoshal, 2002 or Dickmann and Müller-Camen, 2006), it is likely that they have many control and coordination and knowledge transfer assignments (Dowling, Festing, \& Engle, 2013; Edström \& Galbraith, 1977). In addition, it can be seen that firms now distinguish between developmental and business needs assignments, with the latter commanding a more generous expatriation package (RES Forum, 2017). AEs are often treated in the literature as if their employers initiated the first key binding activity in the drive to fill a position abroad. However, where staff urges their employer to send them abroad - i.e. the expatriate themselves undertakes the first key binding step (c.f. Andresen et al., 2014; Heckhausen, 2012) - this could have an impact on the reward package that the organization offers. In turn, individuals have their own sets of individual drivers that influence their decision to (seek) work abroad (Doherty, Dickmann, \& Mills, 2011; Hippler, 2009). Contrasting these with the (organizational) assignment goals, the host context and family situation would give important information to the design of expatriation packages and how difficult (or easy) it might be to persuade particular expatriation candidates to work in a specific job in a determined country. Overall, going beyond the binary distinction of who initiates foreign work (organization - individual) to capture the rich motivational patterns and drivers of global careerists could yield important insights as to 
the design of global mobility strategies and reward approaches. Other distinctions within the category of AEs - e.g. whether these are assigned to their home country, the head office of the organization, to hostile, insecure environments etc. - would give additional nuancing to the IM approaches of organizations.

Selection by the Organization, Negotiation and Pre-Departure Preparation. The literature on how to select appropriate candidates for working abroad is broad and covers a broad spectrum of factors including psychological (Caligiuri, 2013), family (Harvey, 1995), political (Dickmann \& Baruch, 2011; Ferner, Almond, Clark, Colling, Edwards, Holden, \& Mueller-Camen, 2004), cultural (Black \& Stephens, 1989; Haslberger, Brewster, \& Hippler, 2013), performance (Dowling et al., 2013) and specific location (Dickmann, 2013) elements. Clearly, each of the different perspectives incorporates a set of diverse recommendations. Thus, organizational policies could be refined based on an array of different recommendations. Again, understanding the drivers of individuals better, their cultural and work competency stretch to their host environment would be useful for organizations to shape their selection processes so that they can go beyond the 'coffee machine selection' approach (Harris \& Brewster, 1999). In addition, clearly distinguishing AEs who return to a country they have lived in (ex-host country nationals), understanding the elements of their work (AEs who are also frequent business travellers, reward expatriates, just-in-time workers who lack the time to prepare etc.) could give valuable insights. In turn, not distinguishing the richness of the AE population will lead to highly generic recommendations. Individuals, in contrast, will want to understand the importance and pressure to fill a position, the success elements of the work that may be linked to improved careers (Dickmann, Suutari, Brewster, Mäkelä, Tanskanen, \& Tornikoski, 2017; Suutari, Brewster, Mäkelä, Dickmann, \& Tornikoski, 2017) and, crucially, may want to contrast their own drivers with the short- and long-term attractiveness of the expatriation sojourn in order to shape their negotiation strategy and pre-departure preparation. 
Thus, it would be important not just to refine our definitions of IM patterns but also those that relate to the job on offer, the host environment and the career (and other) benefits that are associated with working abroad for a particular organization.

\section{Working Abroad - Unequal Contractual Agreements and HR Management.}

Employers tend to strive for fair, equal and consistent treatment of their staff in order not to break their psychological contract and to encourage motivation and commitment (Conway \& Briner, 2005). However, the absence of clear definitions of who is an international traveller or commuter, who is on a short- or long-term assignment or when (if at all) to convert an assignment contract into a local plus arrangement leads to unfair treatment of IMEs. It is well known (RES Forum, 2015, 2016, 2017) that these different categories of global work are associated with highly distinctive contracts that specify different financial reward levels as well as highly different benefits (travel, accommodation, health insurances, support measures). Moreover, while short- and long-term assignment policies are normally centrally defined (which ensures a higher degree of equal treatment and fairness), international travellers are often flying under the radar screen of IM departments and their higher costs are borne by travel budgets while there are few financial incentives. By not officially categorizing frequent flyers as global careerists, organizations tend to treat them highly differently from AEs breaching their own principles of equality and fairness.

While we argue to increase the fairness of global work compensation, it does not mean one size fits all. It would be useful for MNCs to take account of the specific circumstances of the work abroad. Organizations should tailor their international development approaches in relation to the underlying needs of the work abroad, the host context and the interests of the IMEs, be they officially assignees, frequent travellers or cross-border commuters. It is not as if organizations do not take account of the job demands or security aspects of foreign postings. However, if research would be able to distinguish a range of different elements in relation to 
the individual's and the organization's needs it would be able to create deeper insights and nuance their recommendations. In addition, while many of the career aspects of AEs have been explored, there is considerable uncertainty about the career outcomes of other forms of international mobility - especially those where the work abroad is rolled into a general career system as with frequent flyers or virtual international workers. In contrast, much of performance management when working abroad is conducted through local hosts using the general organizational HR system. It is rare that the strains of expatriate challenges or other issues used for the classification of assignment type such as intention to return are formally taken account of in performance appraisals.

Repatriation and Review of Outcomes. Individual and organizational motivations and goals in relation to the foreign sojourn should be evaluated upon repatriation. However, the general definition of global careerists have so far led to little more than this generic recommendation. If the definitions were more precise, they would allow us to specifically look at whether assignment goals such as development, control and coordination, knowledge transfer, skills filling etc. were fulfilled by the individual. In turn, they would also facilitate an assessment of the key drivers of assignees. To some extent - predominantly in the areas of career, development and marketability - this has been explored in general for SIEs and AEs (Dickmann et al., 2017; Suutari et al., 2017). However, they have not been connected to the specific organizational assignment objectives. In addition, research into the immediate and long-term outcomes of other forms of global mobility could be expanded.

Overcoming the Tensions between Broad Types and Specific Research. We have argued that the existing typologies and associated definitions should be improved in order to allow us to advance research into IMEs. The key challenges include, first: it is currently often impossible to combine insights from different authors as they are using different definitions for certain types of IMEs and different operationalisations. Indeed, the overlap of criteria - e.g. 
both AEs and SIEs are supposed to repatriate (Tharenou, 2015) - and a temporal dimension during which global workers can change 'status' (e.g. from AE to SIE) creates ambiguous distinctions to immigration and may lead to confusion. One way around it may be to make a choice regarding temporal dimensions that relates the type of global worker to a time span (e.g. at the time of moving across national borders or the most recent status in relation to the research). Second, and related, the quality of the general criteria used to define and categorize diverse forms of global work could be improved. Above, we have outlined the current drawbacks of global career typologies in terms of explicitness, consistency, completeness, parsimony, productivity, empirical anchoring and verifiability. The effect of this lack of definitional quality is that the applicability of our practical insights is limited and may have to be reconsidered in terms of its operational and personal value as well as the limitations inherent.

Overall, typologies of global careerists are living with a tension. One way to advance the field, as we have suggested, would be to define the types more explicitly, create a consistent and complete overview which would allow to explore new research questions and to practically apply the findings. However, the challenge in relation to combining the research insights in a parsimonious way is readily apparent. Thus, we suggest to concentrate on less elaborate typologies that are based only on a few criteria and use broad types to subsequently develop research investigating issues within these. One of the examples of such an approach is that of Andresen and her co-authors (Andresen et al., 2014) who use a small number of criteria to distinguish between an array of foreign work forms such as AEs, SIEs, assigned travellers and self-initiated travellers. When global workers relocate across national borders and change their dominant place of residency their approach looks at the legality of work (distinguishing migrants and expatriates), who initiates the first binding activity (distinguishing between AEs and SIEs) and whether the person has changed organizations (e.g. intra-organizational SIEs vs inter-organizational SIEs). The advantage of such a typology is that it is easy to apply 
across a range of research scenarios, that it can be empirically verified and that it leaves out a range of criteria (e.g. intention to stay) that may not be relevant for many research studies.

Thus, in a first step types of international mobility need to be described in a comprehensive way. This might be informed by an interdisciplinary discussion where insights from sociology, psychology, migration studies, ethnography etc. can be used to build a better description of the many types of IMEs. In a second step we would suggest to condense the core descriptors in order to arrive at parsimony. An example of this process can be found in Andresen and her colleagues (2014). In practice, selecting the adequate types to research will be linked to the specific perspective of the scientific study and the purpose pursued. Therefore, step one allows a more integrated and comprehensively exhaustive approach (aiding consistency in the field) while step two factors in the pragmatic needs and specific interests of researchers.

In addition, we outlined above that a clear delineation of types of international mobility will allow organizations to design, evaluate and refine tailored global mobility activities to certain mobile employee groups before, during and after working abroad. Key is often to understand the diverse drivers, interests, backgrounds and experiences that expatriates and other foreign workers have and to utilize these insights to develop targeted global mobility approaches. Using more systematic typologies allows not just single organizations to create distinct global mobility approaches, it would also enable them to learn better from the experiences of other organizations and to apply scientific research to their own globally mobile employee groups.

\section{Conclusions}

As has been shown above, current research in expatriation suffers from the fact that terms are not or not adequately defined, or terms are defined, but used in a different way than others researching the same phenomenon (McNulty \& Brewster, 2016) or suffer from some 
overlap. Thus, it is time to develop an empirically-based theory of expatriates that describes peculiarities of mobility types based on criteria such as international mobility intention, behavior and experience.

All descriptions need to be empirically anchored and statements must be empirically testable. We have suggested two steps that would make sure that researchers work in a comprehensive, integrated and yet parsimonious way. In addition, the concept of peculiarity has to be specified in three respects. Firstly, this means that the characteristics of types are stable in time, and the degree of stability must be quantifiable (days, months, years?). Secondly, peculiarity means that the property under consideration varies between people, not between any people, but between those working for similar kinds of organizations, because it makes no sense to confuse differences in international mobility with organizational differences. Thirdly, extreme features should be excluded because their stability and explanation are often different from those of normal variants of international mobility patterns.

Both researchers and practitioners profit from a parsimonious typology differentiating only few types using a coherent set of criteria. 


\section{References}

Al Ariss, A. (2010). Modes of engagement: Migration, self-initiated expatriation, and career development. Career Development International, 15(4), 338-358. https://doi.org/10.1108/13620431011066231

Anderson, B., \& Blinder, S. (2015). Who Counts as a Migrant? Definitions and their Consequences. $4^{\text {th }}$ Revision. Retrieved from http://www.migrationobservatory.ox.ac. uk/wp-content/uploads/2016/04/Briefing-Who_Counts_as_a_Migrant.pdf

Andresen, M., Bergdolt, F., Margenfeld, J., \& Dickmann, M. (2014). Addressing international mobility confusion - Developing definitions and differentiations for self-initiated \& assigned expatriates as well as migrants. International Journal of Human Resource Management, 25(16), 2295-2318. https://doi.org/10.1080/09585192.2013.877058

Arp, F., Hutchings, K., \& Smith, W. A. (2013). Foreign executives in local organisations: An exploration of differences to other types of expatriates. Journal of Global Mobility: The Home of Expatriate Management Research, 1(3), 312-335. https://doi.org/10.1108/JGM-01-2013-0006

Asendorpf, J. B., \& Neyer, F. J. (2012). Psychologie der Persönlichkeit (5 ${ }^{\text {th }}$ ed). Heidelberg: Springer.

Bailey, K. D. (1994). Typologies and Taxonomies: An Introduction to Classification Techniques. Thousand Oaks, CA: Sage.

Banai, M., \& Harry, W. (2004). Boundaryless global careers: the international itinerants. International Studies of Management and Organization, 34(3), 96-120.

Bartlett, C. A., \& Ghoshal, S. (2002). Managing across borders: The transnational solution. Boston: Harvard Business Press. 
Baruch, Y., Dickmann, M., Altman, Y., \& Bournois, F. (2013). Exploring international work: Types and dimensions of global careers. The International Journal of Human Resource Management, 24(12), 2369-2393. http://dx.doi.org/10.1080/09585192.2013.781435

Black, J. S., \& Stephens, G. K. (1989). The influence of the spouse on American expatriate adjustment and intent to stay in Pacific Rim overseas assignments. Journal of Management, 15(4), 529-544.

Brewster, C., Dickmann, M., Mäkelä, L., \& Suutari, V. (2017). Managing global and migrant workers. In R. Kramar, \& J. Syed (Eds.), Human Resource Management: A Global and Critical Perspective. (2 $2^{\text {nd }}$ ed.). (pp. XXXX). London: Palgrave MacMillan

Briscoe, D., Schuler, R. S., \& Claus, L. (2009). International Human Resource Management. (3rd ed.). London: Routledge.

Caligiuri, P. (2013). Cultural agility: Building a pipeline of successful global professionals. John Wiley \& Sons.

Cerdin, J. L., \& Selmer, J. (2014). Who is a self-initiated expatriate? Towards conceptual clarity of a common notion. International Journal of Human Resource Management, 25(9), 1281-1301.

Chaloff, J., \& Lemaître, G. (2009). Managing highly-skilled labour migration: A comparative analysis of migration policies and challenges in OECD countries. OECD Social, Employment and Migration Working Papers, No. 79. Paris: OECD Publishing. http://dx.doi.org/10.1787/225505346577

Conway, N., \& Briner, R. B. (2005). Understanding psychological contracts at work: A critical evaluation of theory and research. Oxford: Oxford University Press.

Cox, J. L. (1988). The overseas student: Expatriate, sojourner or settler? Acta Psychiatrica Scandinavica, $\quad 78(\mathrm{~S} 344), \quad$ 179-184. http://dx.doi.org/10.1111/j.1600-0447.1988. tb09019.x 
Dickmann, M. (2012). Why do they come to London? Exploring the Motivations of Expatriates to Work in the British Capital. Journal of Management Development, 31(8), 783-800. https://doi.org/10.1108/02621711211253240

Dickmann, M., \& Baruch, Y. (2011). Global Careers. London: Routledge.

Dickmann, M., \& Müller-Camen, M. (2006). A typology of international human resource management strategies and processes. International Journal of Human Resource Management, 17(4), 580-601. http://dx.doi.org/10.1080/09585190600581337

Dickmann, M., Suutari, V., Brewster, C., Mäkelä, L., Tanskanen, J. and Tornikoski, C. (2016). The career competencies of self-initiated and assigned expatriates: Assessing the development of career capital over time. The International Journal of Human Resource Management, 1-25. http://dx.doi.org/10.1080/09585192.2016.1172657

Doherty, N., Dickmann, M., \& Mills, T. (2011). Exploring the motives of company-backed and self-initiated expatriates. The International Journal of Human Resource Management, 22(3), 595-611. http://dx.doi.org/10.1080/09585192.2011.543637

Doty, D. H., \& Glick, W. H. (1994). Typologies as a unique form of theory building: Toward improved understanding and modeling. Academy of Management Review, 19(2), 230251. http://dx.doi.org/10.5465/AMR.1994.9410210748

Dowling, P. J., Festing, M., \& Engle, A. (2013). International human resource management (6th ed.). London: Cengage Learning.

Edström, A., \& Galbraith, J. R. (1977). Transfer of managers as a coordination and control strategy in multinational organizations. Administrative Science Quarterly, 22(2), 248263.

Fee, A., \& Gray, S. J. (2011). Fast-tracking expatriate development: the unique learning environments of international volunteer placements. The International Journal of 
Human Resource Management, 22(3), 530-552. http://dx.doi.org/10.1080/09585192. 2011.543631

Ferner, A., Almond, P., Clark, I., Colling, T., Edwards, T., Holden, L., \& Muller-Camen, M. (2004). Dynamics of central control and subsidiary autonomy in the management of human resources: Case-study evidence from US MNCs in the UK. Organization Studies, 25(3), 363-391.

Harvey, M. G. (1995). The impact of dual-career families on international relocations. Human Resource Management Review, 5(3), 223-244. https://doi.org/10.1016/10534822(95)90003-9

Harris, H., \& Brewster, C. (1999). The coffee-machine system: how international selection really works. International Journal of Human Resource Management, 10(3), 488-500. http://dx.doi.org/10.1080/095851999340440

Haslberger, A., Brewster, C., \& Hippler, T. (2013). The dimensions of expatriate adjustment. Human Resource Management, 52(3), 333-351. http://dx.doi.org/10.1002/hrm.21531

Heckhausen, H. (2012). Motivation and action. Hamburg: Springer Science \& Business Media. Hippler, T. (2009). Why do they go? Empirical evidence of employees' motives for seeking or accepting relocation. The International Journal of Human Resource Management, 20(6), 1381-1401. http://dx.doi.org/10.1080/09585190902909889

Massey, D. S., \& Bartley, K. (2006). The Changing Legal Status Distribution of Immigrants: A Caution. International Migration Review, 39(2), 469-484. http://dx.doi.org/10.1111/ j.1747-7379.2005.tb00274.x

Mayerhofer, H., Schmidt, A., Hartmann, L., Bendl, R. (2011). Recognising diversity in managing work life issues of flexpatriates. Equality, Diversity and Inclusion: An International Journal, 30(7), 589-609. https://doi.org/10.1108/02610151111167043 
McNulty, Y., \& Brewster, C. (2016). Theorizing the meaning(s) of 'expatriate': Establishing boundary conditions for business expatriates. International Journal of Human Resource Management, 28(1), 27-61. http://dx.doi.org/10.1080/09585192.2016.1243567

McPhail, R., Fisher, R., Harvey, M., \& Moeller, M. (2012). Staffing the global organization: “Cultural nomads". Human Resource Development Quarterly, 23(2), 259-276. http://dx.doi.org/10.1002/hrdq.21133

Otto, K., \& Dalbert, C. (2010). New challenges for human resource management: readiness to perform a mobile job and its antecedents. International Journal of Human Resource Management, 21(4), 600-614. http://dx.doi.org/10.1080/09585191003612109

Peltokorpi, V., \& Froese, F. J. (2009). Organizational expatriates and self-initiated expatriates: Who adjusts better to work and life in Japan? The International Journal of Human Resource Management, 20(5), 1096-1112. http://dx.doi.org/10.1080/ 09585190902850299

RES Forum (2017). The RES Forum Annual Report: Dynamic Trends in Global Mobility. London: M. Dickmann.

RES Forum (2016). The RES Forum Annual Report 2016: Beyond Uniformity - A World of Opportunity. London: M. Dickmann.

RES Forum (2015). The RES Forum Annual Report: Global Mobility and the Global Talent Management Conundrum. London: M. Dickmann.

Selmer, J., Andresen, M., \& Cerdin, J.-L. (2017). Self-initiated expatriates. In Y. McNulty, \& J. Selmer (Eds.), Research Handbook of Expatriates (pp. 187-201). Cheltenham, UK: Edward Elgar.

Stilwell, B., Diallo, K., Zurn, P., Vujicic, M., Adams, O., \& Dal Poz, M. (2004). Migration of health-care workers from developing countries: strategic approaches to its management. Bulletin of the World health Organization, 82(8), 595-600. 
Suutari, V., Brewster, C., Mäkelä, L., Dickmann, M. and Tornikoski, C. (2017). The effect of international work experience on the career success of expatriates: a comparison of assigned and self-initiated expatriates, Human Resource Management. http://dx.doi.org/10.1002/hrm.21827

Tharenou, P. (2015). Researching expatriate types: The quest for rigorous methodological approaches. Human Resource Management Journal, 25(2), 149-165.

Thorn, K. (2009). The relative importance of motives for international self-initiated mobility. Career Development International, 14(5), 441-464. http://dx.doi.org/10.1108/ 13620430910989843

Tung, R. L., \& Lazarova, M. (2006). Brain drain versus brain gain: an exploratory study of exhost country nationals in Central and East Europe. International Journal of Human Resource Management, 17(11), 1853-1872. http://dx.doi.org/10.1080/ 09585190600999992

Vance, C. M. (2005). The personal quest for building global competence: A taxonomy of selfinitiating career path strategies for gaining business experience abroad. Journal of World Business, 40(4), 374-385.

Wiles, J. (2008). Sense of Home in a Transnational Social Space: New Zealanders in London. Global Networks, 8(1), 116-137. http://dx.doi.org/10.1111/j.1471-0374.2008.00188.x 
- Assigned expatriate or international assignee: "Employees who are supported by their employers to legally work in a country outside their country-of-origin generally for a duration of more than one year and usually less than five years." (Brewster, Dickmann, Mäkelä, \& Suutari, 20??)

- Boomerang: "These are individuals who have emigrated and are hired by firms in their original home country to return home or are foreigners with experience in the country, who have returned home and are now hired to come back to the foreign country." (Briscoe, Schuler, \& Claus, 2009)

- Business expatriate: People who are organizationally and legally employed and stay abroad for a certain intended length of time (temporary or permanent) as non-citizens of this host country. (McNulty \& Brewster, 2016)

- Corporate or organizational expatriate: "Those who are dispatched by their home companies to international posts" (Peltokorpi \& Froese, 2009).

- Corporate or organizational self-initiated expatriate: A person "who independently initiate mobility abroad within their own organisation under its sponsorship, support and knowledge." (Tharenou, 2015)

- Domestic internationalist: "Employees who never leave home but conduct international business with customers, suppliers, and colleagues in other countries (via telephone, email, fax, or even snail mail)" (Briscoe, Schuler, \& Claus, 2009)

- Ex-host country national: Nationals who return home, after having lived abroad for an extensive period of time (Tung \& Lazarova, 2006).

- Expatriate: People working outside their own country for what they anticipate will be a limited period of time. (Brewster, Dickmann, Mäkelä, \& Suutari, 2017)

- Flexpatriate: Persons whose "work assignments are characterized by a continuation of their current work position in their domestic country combined with work projects in different international destinations, commutes to divers [sic!] cultural settings, assignments on short notice with and flexible travel. On the personal side assignments beyond flexpatriates' domestic country do not involve relocating a home or family." (Mayerhofer, Schmidt, Hartmann, \& Bendl, 2011)

- Foreign Executives in Local Organisations: "FELOs can be viewed as SIEs or, more generally, expatriates (...) who work at executive level, in local organisations, in distant countries". (Arp, Hutchings, \& Smith, 2013)

- Global careerist: "Internationally oriented professionals with a long-term global career involving different types of international work during their careers.” (Brewster, Dickmann, Mäkelä, \& Suutari, 2017)

- Global or international itinerants: Persons who may remain outside their home country for substantial parts of their career. (Banai \& Harry, 2004)

- Global manager: Persons "who are senior executives whose careers during the course of a working life cover frequent (e.g. three or more) international assignments and positions with one or several employers." (Tharenou, 2015)

- Globetrotter: Person who regularly or frequently travels to different places around the world.

- Immigrant (legal / illegal / asylum): “(a) traditional TCNs, employees who are hired to work in a foreign subsidiary but whose home of citizenship is another country, thus they become immigrants to the country of the subsidiary; (b) people hired by the parent firm (either in-country or as new immigrants and brought into the country) to work in the parent country" (Briscoe, Schuler, \& Claus, 2009)

- Inpatriate / impatriate: Persons "who are host or third country nationals the parent company transfers to its headquarters on a semi- or permanent basis usually for development, often to return to manage a subsidiary in their home country" (Tharenou, 2015)

- Intern (or temporary immigrant): “These are workers brought into a firm's home country to work for short (six months to two years) periods as interns or trainees, used especially to fill in for labor shortages." (Briscoe, Schuler, \& Claus, 2009)

- International business traveler: People travelling "frequently to different parts of their company or to clients or prospective clients for visits ranging from days to weeks depending on the task required of them." (Brewster, Dickmann, Mäkelä, \& Suutari, 2017)

- International commuter or cross-border: "Employees who live in one country (home countries) but who work in another (host) country and regularly commute across borders to perform aspects of their work. They may live at home in one country yet commute on a daily or weekly basis to another country to work" (Briscoe, Schuler, \& Claus, 2009)

- International volunteer: Individual with specialist expertise undertaking an international work assignment with specific development objectives. (Fee \& Gray, 2011). 
- Just-in-time expatriate: "These are ad hoc or contract expatriates who are hired from outside the firm as they are needed and just for one assignment." (Briscoe, Schuler, \& Claus, 2009)

- Localized employee: "Often referred to as localization, this normally refers to the situation where an employee is sent to work in a foreign country but hired as a local employee (with some allowances to get over there). This may be because they really want to work in that country, often because they marry a local spouse or for some other reason want to spend the rest of their careers in that location. It may also involve an international assignee who is concerted to permanent local status once the assignment period is over." (Briscoe, Schuler, \& Claus, 2009)

- Migrant: "People moving from their original home country to another country in the expectation that they will spend the rest of their lives in the new country." (Brewster, Dickmann, Mäkelä, \& Suutari, 2017)

- Outsourced employee: "(...) the MNE decides to pay someone else (in another country) for the services of an "employee" or group of employees. (...) global employment companies (...) provide a few employees or whole staffs for overseas locations." (Briscoe, Schuler, \& Claus, 2009)

- Permanent cadre or globalist: "These are employees who spend essentially their whole careers in international assignments, moving from one locale to another." (Briscoe, Schuler, \& Claus, 2009)

- Retirement expatriate: "This refers to the hiring of a firm's retirees for short-term foreign assignments." (Briscoe, Schuler, \& Claus, 2009)

- Returnee: "These are emigrants who are hired (or selected, if already employed by the firm) to return to their home countries to work for the firm there." (Briscoe, Schuler, \& Claus, 2009)

- Reward or punishment assignee: "These are employees who are late in their careers and who are either given a desirable foreign assignment to enjoy and to pad their pensions for when they retire in a couple of years (pay is higher on foreign assignments) or are sent to a difficult locale or undesirable assignment as a way to sideline them to finish out their careers, rather than have to discipline or terminate them because of marginal performance." (Briscoe, Schuler, \& Claus, 2009)

- Second-generation expatriate: "These are naturalized citizens (immigrants who have become citizens) and are sent on foreign assignments to countries other than their countries of birth. The assumption is that, since they have lived through the "expatriate" experience once, they should be better able (than those without this experience) to handle it the second time." (Briscoe, Schuler, \& Claus, 2009)

- Secondee overseas: Overseas secondments are fixed term placements that usually occur between organisations in different countries, with the expectation that the secondee will return to the sending organisation."In a secondment, the initiative to be mobile often comes from the individual." (Thorn, 2009).

- Self-initiated expatriate or self-initiated foreign worker: "People working abroad for what they intend to be a limited, even if quite long in some cases, period, who have made their own way to the country on their own initiative.” (Brewster, Dickmann, Mäkelä, \& Suutari, 2017)

- Short-term (international) assignee: "Person assigned abroad for a period of less than a year (usually less than six months) where the expatriate, even if they have a family, leaves them behind and goes on their own." (Brewster, Dickmann, Mäkelä, \& Suutari, 2017)

- Sojourner: Sojourners are temporary visitors to a foreign country (Cox, 1988)

- Stealth assignee: "International assignees who are relocated by their managers without ever informing HR (that is, they "fly under the radar"), so that they do not show up in the records, benefits, and support systems used to manage such employees." (Briscoe, Schuler, \& Claus, 2009)

- Virtual global employee or virtual international employee: "This is the situation where all or most of the work is performed across borders via electronic media: teleconferences, email, telephone, videoconferences, fax, etc." (Briscoe, Schuler, \& Claus, 2009)

- Skilled (im)migrant: "Managerial, professional and technical persons usually holding at least a bachelor's degree gained in their home country and a skilled occupation, who self-initiate migration for the long-term usually to settle permanently in a new country for reasons of economic motivation, career progress, lifestyle, establishment of better lives and living conditions, and/or family and relationships, either migrating through employer sponsorship of a job in the new country or independently by a skilled migration programme seeking to gain employment once there." (Tharenou, 2015) 
Appendix 2: Criteria used in literature to define IMEs

\begin{tabular}{|c|c|c|}
\hline \multirow[t]{11}{*}{ Mobility } & $\begin{array}{l}\text { Geographical mobility (individual } \\
\text { perspective) }\end{array}$ & $\begin{array}{l}\text { - to the expatriate's original home country; } \\
\text { - to country outside the expatriate's country-of-origin; } \\
\text { - to "new" country }\end{array}$ \\
\hline & $\begin{array}{l}\text { Geographical mobility } \\
\text { (organizational perspective) }\end{array}$ & $\begin{array}{l}\text { - to a firm's home/parent country; } \\
\text { - to foreign subsidiary; } \\
\text { - to a parent company's headquarters; } \\
\text { - to a (local) organization abroad }\end{array}$ \\
\hline & Organizational mobility & $\begin{array}{l}\text { - within the organization } \\
\text { - } \quad \text { between organizations }\end{array}$ \\
\hline & Career-related mobility & $\begin{array}{l}\text { - late in the career; mid-career; } \\
\text { - early career }\end{array}$ \\
\hline & Duration & $\begin{array}{l}\text { - temporary (few days, weeks, months, few to many years) versus permanent (for } \\
\text { the rest of and individual's career/life); } \\
\text { - intended/anticipated versus actual length of time }\end{array}$ \\
\hline & Frequency of travelling & $\begin{array}{l}\text { - commuting; frequent/regular traveling; } \\
\text { - one-time relocation (home, family) }\end{array}$ \\
\hline & Occurrence & $\begin{array}{l}\text { - } \text { one singular mobility } \\
\text { - frequent mobility } \\
\text { - long-term global career } \\
\end{array}$ \\
\hline & Kind of mobility & $\begin{array}{l}\text { - } \quad \text { physical mobility; } \\
\text { - } \quad \text { irtual collaboration } \\
\end{array}$ \\
\hline & Planning horizon & $\begin{array}{l}\text { - } \quad \text { on short notice; } \\
\text { - long-term preparation period }\end{array}$ \\
\hline & Variance (geographically) & $\begin{array}{l}\text { - one country; } \\
\text { - variety of countries }\end{array}$ \\
\hline & Variance (organizationally) & $\begin{array}{l}\text { - one versus several employers; } \\
\text { - one versus different part of the company; } \\
\text { - } \quad \text { to (prospective) clients for visits }\end{array}$ \\
\hline
\end{tabular}




\begin{tabular}{|c|c|c|}
\hline \multirow[t]{6}{*}{ Employment } & Contract partner & $\begin{array}{l}\text { - continuation of current work contract with parent organization in home country; } \\
\text { - hired as a local employee }\end{array}$ \\
\hline & Legality & $\begin{array}{l}\text { - legal employment; } \\
\text { - illegal employment }\end{array}$ \\
\hline & Level/job role & $\begin{array}{l}\text { - (senior) executive; manager; professional; specialist; technical person; worker; } \\
\text { intern; trainee }\end{array}$ \\
\hline & Organizational membership & $\begin{array}{l}\text { - international mobility as one step in a longer-lasting organizational career; } \\
\text { - membership limited to one foreign stay (ad hoc/contract expatriates) }\end{array}$ \\
\hline & Task & $\begin{array}{l}\text { - } \quad \text { assignment; } \\
\text { - } \quad \text { work project }\end{array}$ \\
\hline & Employment status & $\begin{array}{l}\text { - } \text { organizationally employed; } \\
\text { - } \text { self-employed; } \\
\text { - } \text { retiree; } \\
\text { - unemployed }\end{array}$ \\
\hline \multirow[t]{6}{*}{ Conditions } & Citizenship/origin & $\begin{array}{l}\text { - non-citizen of the host country/ foreigners; } \\
\text { - foreigner who became citizen of the host country/ naturalized citizen; } \\
\text { - third-country national; } \\
\text { - } \text { host-country national }\end{array}$ \\
\hline & Educational level & $\begin{array}{l}\text { - at least a bachelor's degree } \\
\text { - etc. }\end{array}$ \\
\hline & Educational (non-)residents & $\begin{array}{l}\text { - degree gained in their home country } \\
\text { - degree gained in their host country }\end{array}$ \\
\hline & Employee's emotional attachment & $\begin{array}{l}\text { - to home country and/or } \\
\text { - to host country }\end{array}$ \\
\hline & Initiation & $\begin{array}{l}\text { - employee independently initiates mobility abroad; } \\
\text { - employer initiates mobility abroad }\end{array}$ \\
\hline & Motives & $\begin{array}{l}\text { - organization (e.g. fill in for labor shortages; reward; punishment; development, } \\
\text { often to return to manage a subsidiary in the expatriate's home country); }\end{array}$ \\
\hline
\end{tabular}




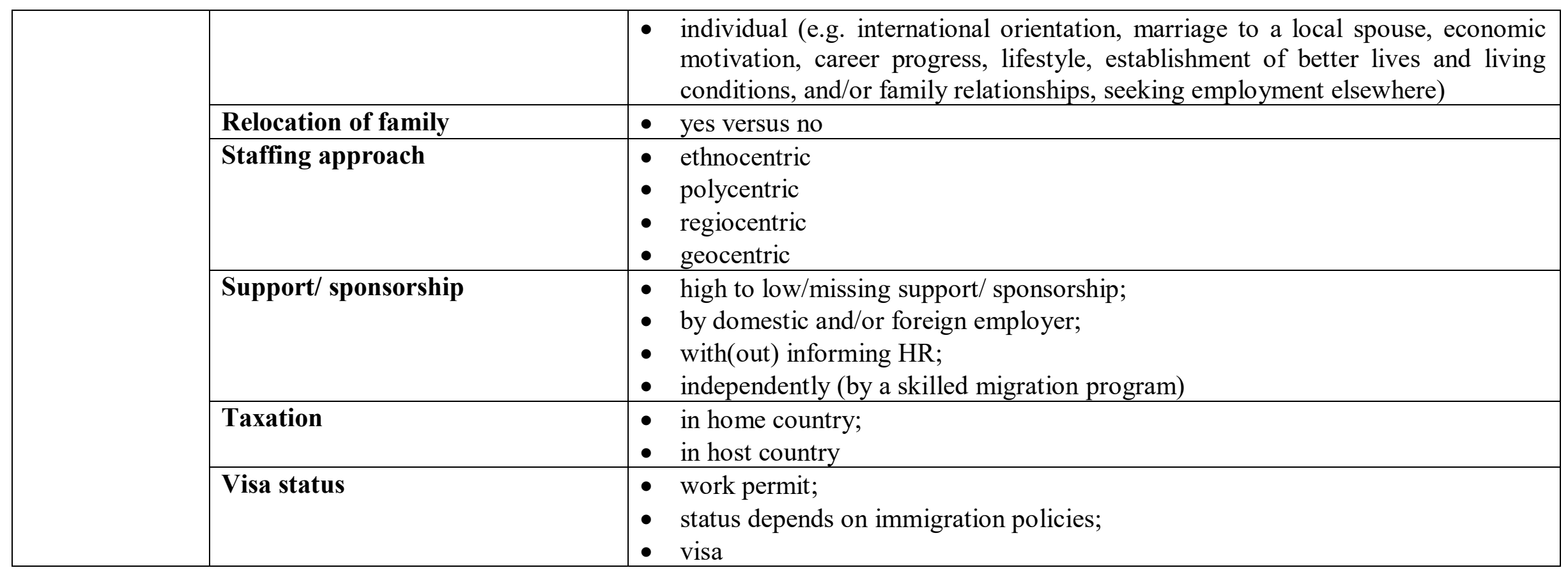

